\title{
錨泊における走錨検知に関する基礎的研究
}

\author{
井上 欣三*・臼井 英夫*・品川 史子**
}

\section{A Study on Detecting the Risk of Dragging Anchor}

\author{
Kinzo INOUE, Hideo USUI and Fumiko SHINAGAWA
}

\begin{abstract}
While a ship is anchoring, if the external force exceeds the holding force, the anchor moves and turns little by little. At last, dragging anchor starts. For officers, at anchor watch, it is very important to know the posture of the anchor. But, it is difficult to know it, because nobody can see the situation of the anchor on the seabed.

In this paper, a monitoring system to detect the risk of dragging anchor is proposed. A sensor is attached at the specified point of the anchor chain to measure the height of sensor from seabed. And, on the basis of the relationship between risk index of dragging anchor and the change of height of the sensor, the risk of dragging anchor can be judged.
\end{abstract}

Keywords : Anchoring, Dragging Anchor, Monitoring system キーワード：錨泊、走錨、補助システム

\section{1. はじめに}

荒天時に錨泊している船舶の操船者にとって重要 なことは、走錨を早期に検知し、錨泊の安全を確保 することである。従来行われてきた守錨法では、周 期的な振れ回りが無くなり風を同じ舷から受けるよ うになる、正横の見通し線から船位の変位が認めら れるなど、走錨現象がおこってからの検知にとどま っていた。走錨の検知が遅れれば遅れるほど、次善 の対応が取りにくくなるばかりでなく、周囲の船舶 や構造物への衝突、乗り揚げといった事故を引き起 こすことにもつながる。

現在行われている走錨判断では、走錨が検知され た時点では既に一定速度で圧流されている状態であ るといえる。また、船員の経験や感覚に依存した判 断となっているといえる。船体が圧流されだした後 に講ずる措置も重要であるが、走錨の危険をいち早 く察知することの方がより重要であろう。このこと より、走錨の危険を早期に判断し、対処できる新た な走錨危険の判断材料として考えられるのが、ここ に提案する走錨検知システムのイメージである。
ここにいう走錨検知システムとは、海中に存在す る錨鎖のカテナリー形状に着目し、これから得られ る情報をもとに走錨の危険が存在するか否かを判断 し、走錨する前に措置を行うことができるように当 直者にアラームなどで危険を周知させ、走錨を回避 することを目的としたシステムである。

具体的に述べると、錨泊中の船舶の錨鎖は海中で はカテナリー曲線を描いておう、船体に加わる外力 が小さければ海底に寝ている錨鎖が長くなり、カテ ナリー部は Slack 状態となる。反対に、外力が大き くなれば海底に寝ている錨鎖は短くなり、カテナリ 一部は Taut 状態となる。つまり、外力が加わるほど 錨鎖は Slack 状態から Taut 状態へと移り変わる。こ の錨鎖のカテナリー形状の変化に着目し、何らかの センサーを錨鎖の特定の位置に取り付け、常時、そ のセンサーの海底からの高さを測定する。そして、 船橋にモニタを設置し、センサーからの情報や振れ 回りの様子などをモニタする。センサーの測定値が 走錨の危険が迫っていると判断される高さにくるよ

* 正会員 神戸商船大学 （广658-0022 神戸市東灘区深江南町 5-1-1） k-inoue@cc.kshosen.ac.jp

** 学生会員 神戸商船大学大学院 
うになると、船橋に設置されたアラームなどにより 危険を知らせ、走錨を回避する措置をとるように促 すものが走錨検知システムの考え方である。

つまり、錨泊船の振れ回り運動によって形成され る錨鎖のカテナリー形状の変化に着目し、錨鎖の特 定の位置と海底との高さを求める。そして、その点 の高さの変化と、錨・錨鎖への作用力の関係をもと に、走錨危険指数、走錨確率という走錨危険性の判 断要素(1)を用いて、走錨の危険が切迫しているか否 かを判断する。本研究は、このような手順のもとで、 走錨の危険発生情報をいち早く操船者に提供するた めの走錨判断方法を確立することを目的としている。

なお、実際に取り付けられるセンサーとしては、 トロール漁船において用いられている超音波発信器 に近いものをイメージしている。また、錨鎖への取 り付け方法については、投錨作業終了後に、錨鎖に 沿わせながらセンサーを降下し、所定の位置に留め ることをイメージしている。具体的なセンサーの構 成、取り付け方法などについては、技術的に解決す ベき問題も多く残されており、次報における検討課 題とする。

\section{2. 錨鎖に取り付けるセンサ一位置の検討}

矢吹らは、錨泊船の振れ回り運動における走錨の 危険を検知する方法として、錨泊状態モニ夕装置を 提案している( ${ }^{(2)}$ 。この研究では、走錨のおそれの判 断基準は、海底に横たわる錨鎖の長さがなくなった 時としている。また、錨の位置は固定とし、移動し ないものとして取り扱っている。さらに、錨に作用 する力と走錨の危険の程度の関係には触れていない。

振れ回り運動は本来動的なものであり、錨に加わ る力が把駐力を超えた時には、錨は移動する。その ため、走錨の検知にあたっては、錨に加わる力とと もに、錨の移動を考慮する必要があり、それに加え
て錨への力のかかり具合が走錯発生の危険性の程度 にどのように結びつくかの定量的相互関連性が明確 でなければならない。

本研究において提案する走錨検知は以下の手順に したがう。(1)錨の特定の位置にセンサーを取り付け ることを検討する。(2)海底からセンサーまでの高さ から、錨鎖の形状をカテナリー形状と仮定すること により、錨に㗢く外力を推定する。(3)錨への作用力 と走錨危険指数、走錨確率との関連性加ら走錨発生 の危険を判断する。

ここで重要となるのは、センサーの取り付け位置 である。センサー取り付け位置の条件としては、(1) 振れ回り運動中にセンサーが水面上に出ることがな い、(2)振れ回り運動中にセンサーが海底に接地する ことがない、(3)錨鎖の上下変動をセンサーにより感 度よく取り出すことができる、ことである。

Fig. 1 は、単錨泊時の錨鎖の海中での状態を示し たものである。

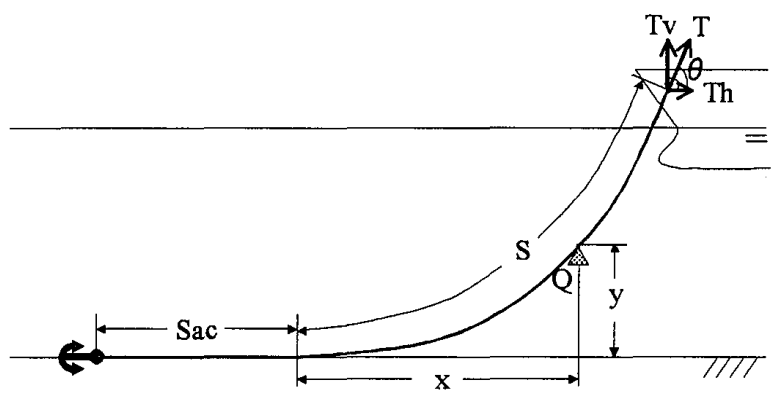

Fig. 1 Posture of anchor chain in water

図中の記号は以下の通りである。

$\mathrm{Q}$ : センサー取り付け位置

$\mathrm{Sac}$ : 海底部に寝ている錨鎖の長さ $(\mathrm{m})$

$\mathrm{S}$ : カテナリー部の長さ $(\mathrm{m})$

$\mathrm{x}$ :錨鎖の立ち上がりからセンサーまでの水平距離 (m)

Table 1 Principal of test ships

\begin{tabular}{|c|c|c|c|c|c|c|}
\hline \multirow{2}{*}{$\begin{array}{l}\text { Type of ship } \\
\text { Condition }\end{array}$} & \multicolumn{2}{|c|}{$\begin{array}{c}\text { PCC } \\
\text { (6000Cars) }\end{array}$} & \multicolumn{2}{|c|}{$\begin{array}{c}\text { Container } \\
\text { (3700TEU) }\end{array}$} & \multirow{2}{*}{$\begin{array}{c}\begin{array}{c}\text { Bulk } \\
\text { carrier }\end{array} \\
\text { Ballast }\end{array}$} & \multirow{2}{*}{$\begin{array}{c}\text { Tanker } \\
\text { Ballast }\end{array}$} \\
\hline & Ballast & Full & Ballast & Full & & \\
\hline Length (m) & \multicolumn{2}{|c|}{210.0} & \multicolumn{2}{|c|}{237.0} & 315.0 & 311.0 \\
\hline Breadth (m) & \multicolumn{2}{|c|}{32.2} & \multicolumn{2}{|c|}{32.2} & 52.0 & 58.0 \\
\hline Draft (m) & 7.50 & 9.33 & 7.33 & 11.80 & 9.03 & 8.55 \\
\hline Dead Weight (ton) & 24,540 & 32,889 & 38,301 & 69,051 & 122,317 & 111,562 \\
\hline Weight of anchor (ton) & \multicolumn{2}{|c|}{10.5} & \multicolumn{2}{|c|}{12.3} & 12.68 & 14.1 \\
\hline Weight of chain $(\mathrm{kg} / \mathrm{m})$ & \multicolumn{2}{|c|}{143.7} & \multicolumn{2}{|c|}{165.8} & 720.0 & 824.85 \\
\hline Diameter of chain (mm) & \multicolumn{2}{|c|}{81.0} & \multicolumn{2}{|c|}{87.0} & 219.0 & 255.4 \\
\hline
\end{tabular}


$\mathrm{y}:$ センサーから海底までの高さ (m)

$\mathrm{T}$ : 張力 (kgf)

$\mathrm{Th}$ : 張力の水平分力 $(\mathrm{kgf})$

$\mathrm{Tv}$ : 張力の垂直分力 $(\mathrm{kgf})$

Table 1 に、計算対象とした船舶の要目を示す。ア ンカーは JIS 型及び AC-14 型とした。アンカーの把 駐係数は、底質が砂の場合 JS 型 3.5、AC-14 型 7.7、 泥の場合 JS 型 3.2、AC-14 型 10.6 とした。また、 錨鎖の把駐係数は、底質が砂の場合 0.75 、泥の場合 1 とした。

Fig. 2 は、錯鎖に取り付けたセンサーの海底から の高さと外力との関係を例示したものである。計算 条件は、対象船舶を PCC のバラスト状態、錨を JIS 型、錨鎖伸出長を 10 節、底質を砂、海底からベルマ ウスまでの高さを $30 \mathrm{~m}$ としている。ここで、Pは、 外力と係駐力が等しい時の外力の大きさ、すなわち 係駐限界の值を示している。また、センサーの取り 付け位置はジョイニングシャックルを想定した。

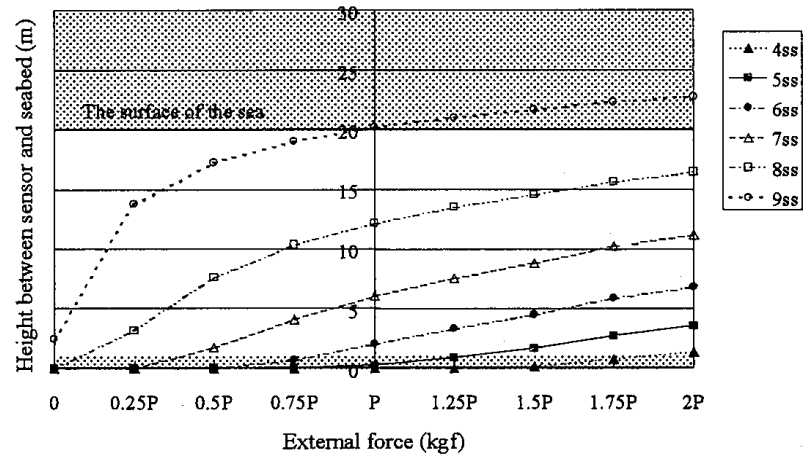

Fig. 2 Relationship between external force and the height of sensor from seabed

Fig. 2 において、網掛けした部分は、水面及び海 底を示している。前述のセンサ一取り付け位置の条 件より、センサー位置は、外力が変動しても、網掛 け部分に入らないことが望ましい。錨から9節目の ところにセンサーを取り付けた場合、外力が大きく なると空中に出てしまう。また、錨から 6 節目まで の間にセンサーを取り付けた場合、海底に接地して しまう場合がある。そのため、センサ一の取り付け 位置は、錨鎖の上下変化を感度よく検出する意味か らも錯から7節目又は 8 節目の位置に取り付けるこ とが望ましいことが分かる。すなわち、伸出した錨 鎖長から 2 節または 3 節引いた節数目の位置にセン サーを取り付けることが望ましいといえる。同様の 検討を、船種船型、コンディション、水潹、錨種類、 錨鎖伸出長、海底底質を変えて行った。いずれの条 件設定からも、錨鎖伸出長から 2 節または 3 節引い た節数目の位置にセンサーを取り付けるのが、もつ
とも有効であるとの結果を得た。

以上の検討から、先に挙げた(1)水面上に出ない、 (2)海底に接地しない、(3)感度がよい、の条件を満た すセンサーの取り付け位置は、錨鎖伸出長から 2 節 または 3 節引いた節数目の位置であることが分かっ た。

\section{3. センサー取り付け位置の上下変動と走 錨危険指数との関係}

Table 1 に示した船舶を対象に、数值シミュレー ションを行い、錨泊船の振れ回り運動を考慮した時 のセンサーの取り付け位置の妥当性を検証するとと もに、センサーの最大高さと、走錨危険指数との関 係について検討を行った。

Fig. 3 は、数值シミュレーションによって取り出 された、時々刻々の錨鎖張力と係駐力及び錯鎖伸出 長から 2 節または 3 節引いた節数目の位置に取り付 けたセンサーの海底からの高さの変化の一例を示し ている。計算条件は、対象船舶を PCC のバラスト状 態、錨を JIS 型、錨鎖伸出長を 10 節、底質を砂、水 深・喫水比 2.0 、風は定常風とし、風速 $20 \mathrm{~m} / \mathrm{s}$ として いる。

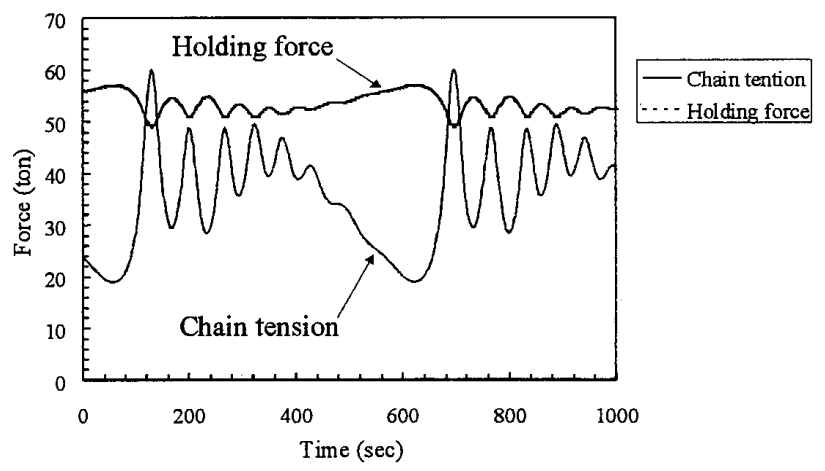

(a) Change of chain tension and holding force

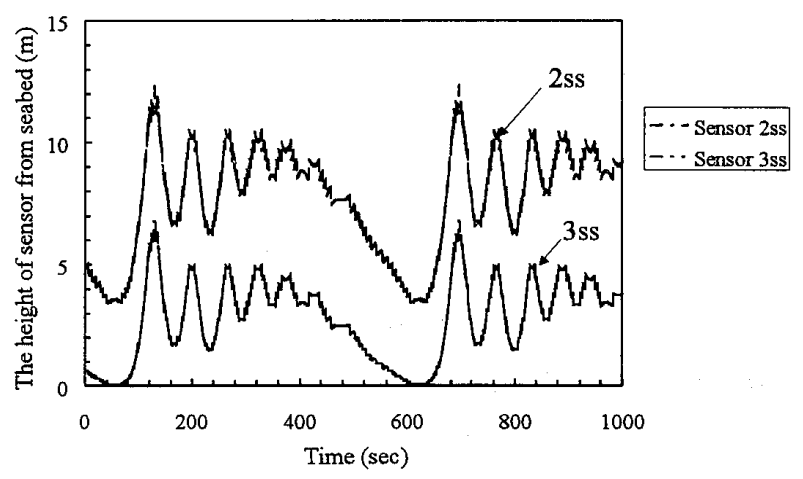

(b) Change of the height of sensor from seabed

Fig. 3 Relationship between vertical movement of sensor and chain tension

Fig. 3 より、船体に外力が加わり、錨に働く張力 が変動するに伴い、センサーも上下動していること 
が分かる。また、張力の值が大きくなると、センサ 一の位置も高くなっている。

また、係駐力と張力の関係に着目すると、張力が 係駐力を超える場合が生じている。この時は、錨の 移動が発生することを示している。したがって、張 力が係駐力を幾たびも大きく超えることにより、走 錨の危険が迫ってくるといえる。

そして、錨鎖張力の変化とセンサーの海底からの 高さの変化は、よく一致していることが分かる。同 様の検討を、船種船型、コンディション、水深・喫 水比、風速を系統的に変化させて行った結果、錨鎖 伸出長から 2 節または 3 節引いた節数目の位置に取 り付けたセンサーの海底からの高さの変化は、錨鎖 張力の変化とよく一致するとともに、伸出錨鎖長加 ら 2 節または 3 節引いた節数目の位置にセンサーを 取り付けることは、錨鎖の上下変動を感度よく取り 出すことができるという観点からも妥当であること が分かった。

次に、走錨危険指数とセンサーの海底からの高さ との関係について検討を行った。Fig. 4 は、錨鎖伸 出長から 2 節引いた節数目の位置に取り付けたセン サーの数值シミュレーション中における最大高さと、 走錨危険指数との関係を示している。計算条件は、 対象船舶を PCC のバラスト状態、錨を JIS 型、錨鎖 伸出長を 10 節、底質を砂、風は定常風之し、風速 $10 \mathrm{~m} / \mathrm{s}$ から $30 \mathrm{~m} / \mathrm{s}$ 、水深・喫水比を 1.5 から 4.0 まで、 としている。

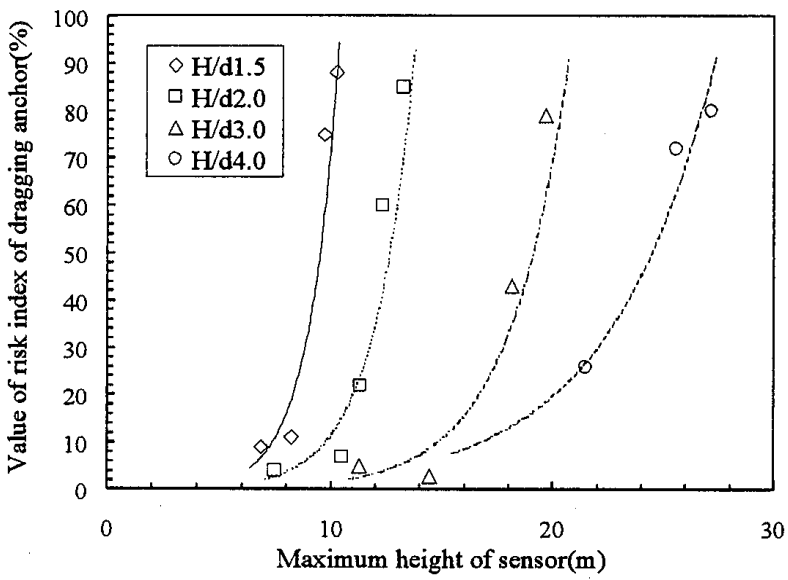

Fig. 4 Relationship between maximum height of sensor and value of risk index of dragging anchor

Fig. 4 より、センサーの海底からの最大高さが大 きくなるにつれて、走錨危険指数は急激に大きくな ることが分かる。また、水深・喫水比が大きくなる、 すなわちより深い水深のところで錨泊する場合、同 じ走錨危険指数の大きさとなるセンサーの海底から
の最大高さはより高くなることが分かる。また、図 から分かるように、センサーの海底からの最大高さ と走錨危険指数との間には一定の関係があるといえ る。そこで、センサーの最大高さを説明変数に、走 錨危険指数を従属変数として、H/d ごとに指数近似 を行い、以下に示す関係式を得た。

$\mathrm{H} / \mathrm{d}: 1.5 \mathrm{RI}=0.0373 \mathrm{e}^{0.758 \% \mathrm{Hm}}$ 相関係数: 0.952

$\mathrm{H} / \mathrm{d}: 2.0 \quad \mathrm{RI}=0.0437 \mathrm{e}^{0.5576 \mathrm{Hm}}$ 相関係数: 0.933

$\mathrm{H} / \mathrm{d}: 3.0 \quad \mathrm{RI}=0.0380 \mathrm{e}^{0.3766 \mathrm{Hm}} \quad$ 相関係数: 0.886

$\mathrm{H} / \mathrm{d}: 4.0 \quad \mathrm{RI}=0.3067 \mathrm{e}^{0.2085 \mathrm{Hm}} \quad$ 相関係数: 0.982

ただし、

$\mathrm{RI}$ : 走錨危険指数 $(\%)$

$\mathrm{Hm}$ : センサーの最大高さ $(\mathrm{m})$

これにより、どのような船が、どのような錨泊条 件で錨泊する時、その時のセンサーの高さがどれ程 にあると、走錨危険指数がどの程度となるかを関連 づけるデータを得ることができた。つまり、センサ 一の海底からの高さを測定することにより、走錨危 険指数を知ることができ、したがって、走錨の危険 限界に対応する走錨危険指数の範囲が与えられれば、 早い時期に走錨の危険が切迫していることを知るこ とが可能となる。

\section{4. 走錨危険の判断方法}

Fig. 5 は、走錨危険指数と走錨確率の対応関係を プロットしたものである(1)。両者はかなりよい対応 関係を示している。つまり、走錨危険指数が $30 \% よ$ り小さい範囲においては走錨確率の值はほぼ同程度 に低い。また、走錨危険指数が $70 \%$ 超える範囲に おいては対応する走錨確率の值は急激に大きくなる。 したがって、走錨危険指数が $30 \%$ 以内にあるならば、 その錨泊条件下では実際に走錨に至る危険性は小さ く、走錨危険指数が $70 \%$ を超えると走錨に対する信 頼性は急速に失われる状態にあるといえる。これら のことより、走錨危険指数が $30 \%$ 70\%の範囲は走

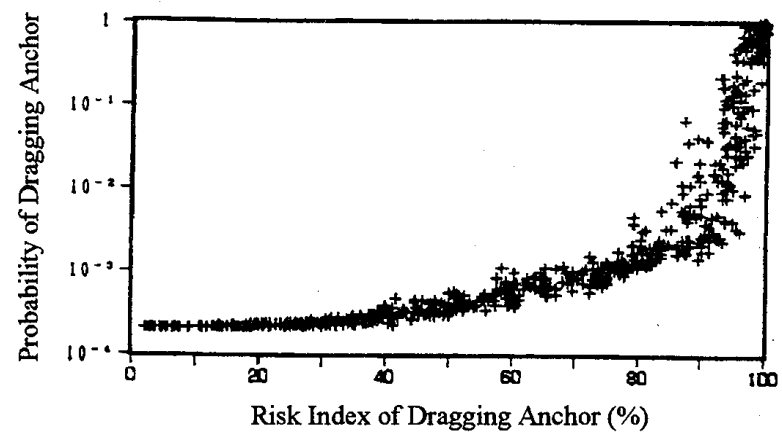

Fig. 5 Relationship between risk index of dragging anchor and probability of dragging anchor 
錨の危険が切迫しつつある要注意域として位置付け ることができる。

Fig. 6 は、走錨危険指数が $30 \%$ 70\%の範囲にな る時の、センサーの最大高さを求めるためのダイヤ グラムの一例である。このダイヤグラムは、対象船 舶を PCC のバラスト状態、錨を JIS 型、錨鎖伸出長 を $8 、 10 、 12$ 節、水深・喫水比を $1.5 、 2.0 、 3.0 、 4.0$ 、 底質を砂として求めたものである。また、センサー 取り付け位置は、錨鎖伸出長から 2 節引いた節数目 の位置とした。

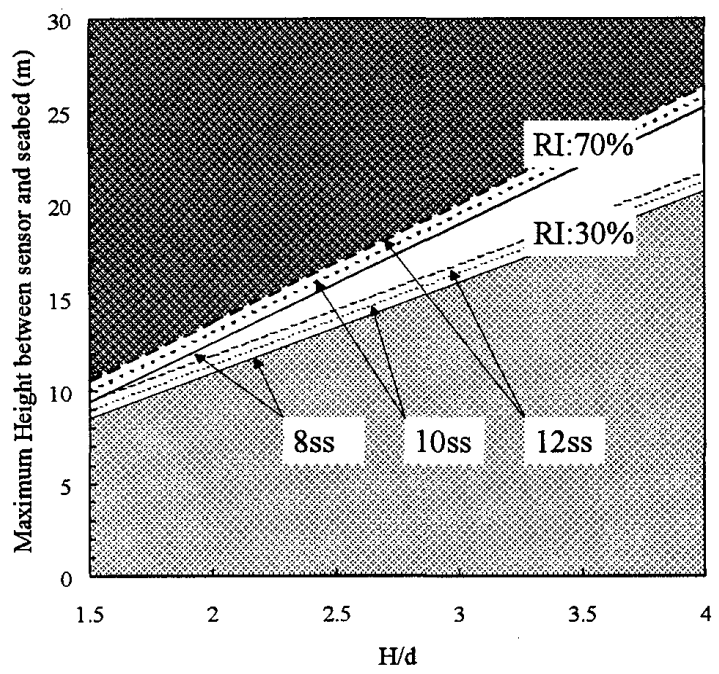

Fig. 6. Diagram for judgment of risk of dragging anchor

Fig. 6 より、操船者は、例えば水深・喫水比 3.0 の 錨地に、錨鎖伸出長 10 節をもって錨泊した場合、セ ンサーの最大高さが $15 \mathrm{~m}$ 以下であれば、走錨危険指 数が $30 \%$ 以下となって走錨の危険が無いと判断す ることができる。また、 $15 \mathrm{~m}$ 以上となるような場合、 走錨の危険が切迫しつつあり、要注意の状況である と判断できる。さらに、18m となった場合には走錨 危険指数が $70 \%$ となり、走錨の危険が大きくなった と判断することができる。このようなダイヤグラム を用いることにより、操船者は、走錨が現実になる 前に、走錨の危険をいち早く判断することが可能と なる。この判断ロジックを走錨検知システムに組み 込むことにより、走錨の危険が切迫していると判断 される時、船橋内にアラームなどで知らせることが 可能となる。

\section{5. おわりに}

船舶にとっては、入港待機のための沖待ちや荒天 避泊等といった錨泊の機会が多い。特に、荒天錨泊 は、困難かつ危険をはらむ。また、通常時の錨泊に おいても、常に危険が存在することを認識しなけれ ばならない。
錨が把駐力を失い、船体が風下に圧流される現象 である走錨は、一旦発生し、定常的な圧流状態とな ると船体姿勢を立て直すことは困難であり、他船へ の衝突、陸岸への乗り揚げなどの海難が発生する。 海難が発生すると、自然環境や生態系の破壊等とい った二次災害の発生も懸念される。したがって、錨 泊中には、できる限り早い時期に走錨の危険を察知 し、対策をとることが危険回避につながるため、走 錨発生の危険性をいち早く予測検知することが重要 である。

本研究では、海中の錨鎖形状に着目し、錨鎖の特 定位置にセンサーを取り付け、海底との高さを常時 測定することで、走錨する可能性のある錨鎖形状を 知るとともに、走錨危険の有無を判断し、走錨前に 所要の措置を行うことができるよう、船内にアラー ムなどで危険を知らせることを目的とした走錨検知 システムのアイデアを提案した。

本提案に関連して得られた成果を以下にとりまと める。

（1）センサーを錨鎖のジョイニングシャックルに取 り付けると仮定し、センサーが有効に働く位置 を検討した。その結果、いかなる条件において も、錨鎖伸出長から、2〜3 節引いた位置が有効 であることが明らかとなった。

（2）錨泊船の振れ回り運動を数值シミュレーション により再現することによって、振れ回り中にお ける張力とセンサーの高さ変化、走錨危険指数 との相互関係を求め、三者の対応関係を明らか にした。

（3）走錨危険指数の $30 \%$ 以下が安全域、 $70 \%$ 以上が 危険域とする考え方をもとに、この安全域と危 険域の間の範囲を走錨に対する要注意域と位置 付け、この状態に対応するセンサー高さの範囲 を走錨の危険を判定するための判断基準とした。

今後、実船に用いるセンサーの種類、形状、取り 付け方法を検討する予定である。また、実際に錨泊 している船舶に搭載し、走錨検知のための情報シス テムとしての有効性を検証する予定である。

\section{参考文献}

（1）井上欣三・臼井英夫:走錨危険指数から見た錨泊 の設計指針一風速、水深之錨鎖一, 日本航海学会 論文集, 90 号,pp.233-241, 平成 6 年 3 月

(2) 矢吹英雄・山下勝博 - 斎藤重信:実船実験による 守錨基準の検討と錨泊状態モニ夕装置の提案, 日本航海学会論文集, 108 号,pp.67-73, 平成 15 年 3 月 


\section{質疑応答}

芳村 康男（北海道大学）：走錨を検知する方法と して、ニニークなアイデアを提案されました研究に 敬意を表します。この方法では、索の深度を計測す る水中超音波発信器を投錨時に然るべき索の位置に 取り付ける必要があります。この発信器の大きさは 現状のトロール網等に使用されている発信器を考え ると必ずしも小型・軽量ではありません。現状の投 揚錨システムにこうした取り外し可能な装置を現実 問題として取り付けることが可能でしょうか?

白井 英夫 : 本研究では、センサーを用いた走錨検 知方法の基礎的な検討をしております。具体的なセ ンサーの内容については今後検討していく所存です。 センサーの取り付けについては、投錨作業終了後セ ンサーを錨鎖に沿わせながら、所定の位置にまで降 下させることをイメージしております。具体的なセ ンサーの構成、取り付け方法について、技術的サポ ートをメーカから頂きながら、実現すべく検討を進 めていきたいと考えております。 